\title{
Using Archives in the Czech Republic as an Important Formative Factor of Historical Awareness and a Means of Providing Publicity For Archives: Archival Exhibitions
}

\author{
MARIE RYANTOVÁ, PH.D., ASSIT. Prof. \\ The Institute of Archival Science and Auxiliary Historical Sciences of the Faculty of Arts at the South Bohemian \\ University in České Budějovice \\ e-mail: ryantova@ff.jcu.cz
}

Using Archives in the Czech Republic as an Important Formative Factor of Historical Awareness and a Means of Providing Publicity For Archives: Archival Exhibitions

\section{ABSTRACT}

Besides using archives for the scientific, economic or economic-operational, legal and administrative purposes, also cultural and educational, or political purposes play an important part. The special archival exhibitions belong (beside the lectures) to the most interesting and attractive forms of the using archives already since the 50 's of the $20^{\text {th }}$ century - both, the greatest and as well as quite small in the individual archives, use the richness of the row of archives. The new archives buildings in the Czech Republic with the exhibition rooms or at least the showcases give a suitable opportunity for it also. The archival exhibitions have even specific financial and personal requirements, but serve also to propagate the archives and have an invaluable significance for the formation of historical awareness in both nationwide and regional scale.

Key words: Czech Republic, Using Archives, Archival Exhibitions, the National Archives, the Ntional Museum Archives, the Archives of the City of Prague

L'utilizzo degli archivi nella Repubblica Ceca come importante fattore formativo della consapevolezza storica e come mezzo per ottenere pubblicità per gli archivi: le mostre archivistiche

\section{SINTESI}

Oltre all'utilizzo degli archivi per fini scientifici, economici o economico-operativi, legali ed aministrativi, giocano un ruolo importante anche quelli culturali ed educativi o politici. Le mostre archivistiche speciali appartengono da sempre (oltre alle conferenze) alla più interessante ed attraente forma di utilizzo degli archivi dagli anni cinquanta del XX secolo - sia le più grandi, che utilizzzano la ricchezza degli archivi, che quelle minori. I nuovi edifici archivistici nella Repubblica Ceca con le sale espositive o almeno le bacheche forniscono essi pure un'opportunità adatta. Le mostre archivistiche hanno anche specifici bisogni finanziari e personali, ma servono anche a diffondere gli archivi ed hanno un significativo valore per la formazione di una coscienza storica sia nazionale che regionale.

Parole chiave: Repubblica Ceca, utilizzo degli archivi, mostre archivistiche, archivi nazionali, Archivio del Museo nazionale, Archivio della città di Praga

Uporaba arhivskega gradiva na Češkem kot pomemben faktor oblikovanja zgodovinske zavesti in način predstavljanja arhivskega gradiva javnosti: arhivske razstave

\section{IZVLEČEK}

Poleg uporabe arhivskega gradiva za znanstvene, ekonomske ali gospodarsko operativne, pravne in upravne namene, igra pomembno vlogo tudi uporasba gradiva za kulturne, izobraževalne ali politične namene. Že od petdesetih let 20. stoletja sodijo posebne arhivske razstave, poleg predavanj, med najbolj zanimive in privlačne oblike uporabe arhivskega gradiva. To velja za tako največje kot tudi za zelo majhne razstave $\mathrm{v}$ posameznih arhivih, na kasterih je predstavljeno bogastvo posameznega arhiva. Nove arhivske zgradbe v Češki republiki z razstavnimi prostori ali vsaj vitrinami, nudijo ustrezno priložnost za takšno dejavnost. Arhivske razstave imajo 
Marie RYANTOVÁ: Using Archives in the Czech Republic as an Important Formative Factor of Historical Awareness and a Means of Providing Publicity For Archives: Archival Exhibitions, 171-180

tudi posebne finančne in druge zahteve. Služijo tudi širi popularizaciji arhivov in imajo neprecenljiv pomen za oblikovanje zgodovinske zavesti tako $\mathrm{v}$ nacionalnem in regionalnem merilu.

Ključne riječi: Češka republika, uporaba arhicskega gradiva, arhivske razstave, Nacionalni arhiv, archiv Nacionalnega muzeja, mestni arhiv Praga

Využívání archivů v České republice jakožto důležitý činitel formování historického vědomí a prostředek zviditelňování archivů: archivní výstavy

\section{ABSTRAKT}

Kromě využívání archivů a archiválií pro vědecké, hospodářské či hospodářsko-provozní a právní či správní účely hrají významnou roli také účely kulturní a osvětově výchovné, případně politické. Mezi nejzajímavější způsoby využívání archiválií $\mathrm{k}$ těmto účelům patří v České republice již od padesátých let 20. století vedle přednášek také speciální archivní výstavy, od největších, které využívají bohatství celé řady archivů, po nerozsáhlé, pořádané pouze jednotlivými archivy; cennou možnost $\mathrm{k}$ tomu poskytují také nové archivní budovy $\mathrm{v}$ ČR, v nichž se často nacházejí i výstavní prostory či alespoň vitriny. Archivní výstavy sice vyžadují specifické finanční a personální nároky, ale slouží i k propagaci archivů a mají také neocenitelný význam i pro utváření historického vědomí jak na celostátní, tak regionální úrovni.

\section{Introduction}

Archival science has long represented an important part of society-wide information system. Its primary task is to collect and maintain the remains of former human existence and both the activities and results of human awareness and knowledge, which have a significant and permanent historical, cultural and social value. Other tasks involve its recording and processing. No less important as the archives' function is accessing the archive's wealth, i.e. presenting the results of former activity to the public and its subsequent use. In this sense, the accessing and usage of archive documents represents a culmination of the archives' activities. Without the usage of archive documents, their storage and other archival activities, but also the existence of archives, become self-serving - it is possible to say that the amount of information provided by the archives influences the degree of their general social usefulness. While taking over, focusing, storing, protecting and recording the archive documents have rather the characteristics of mechanical activity, and processing, e.i. arranging, stocktaking or cataloging represent creative activity, accessing has mainly informative nature. A major prerequisite for using the archive documents is proper recording and subsequent proper and rigorous arranging of the archive material - as well as the subsequent informing about it and its propagation, e.i. various reports on arranged archive funds and than presenting archive tools (listing of funds and collections, archives guide, inventory, catalogs, indexes, etc.).

Archive documents stored in different form in different types of archives, as documents, which were ,selected in the public interest for permanent preservation with regard to time of their creation, content, origin, external relations and lasting value obtained due to political, economic, legal, historical, cultural, scientific and informational" (Zákon o archivnictví a spisové službě (Archives Act), 2004), serve primarily as resource for studying different questions from fields listed above - both for the needs of historiographical research and often for practical use, namely of legal or administrative nature. The use of archive documents, whose policies are defined in Czech Republic by the Archiving and record management law and other implementing regulations ${ }^{1}$, fulfills various objectives and goals: scientific, economic or economic-operational, legal and administrative, but also political or cultural and educational.

Scientific objectives are the most common, whether it is solving various general or specific historical issues, or history of different sectors of human activity, and the results of this use are published in different types of scientific publications and contribute to the historiographical research development. The use of archive documents for the economic and economic-operational purposes (including various legal questions) serves the needs of individuals and organizations, for example, solving different speci-

1. Within the framework of the Archives Act, this represents only general information - $₫ 46,2 \mathrm{f}$ (National Archives), $₫$ 46, 2d (State Regional Archives) and \$ 62, 2c (annual report). 
fic issues or legal disputes, studying old maps and plans in case of building repair or reconstruction of different objects or tracing previous technological procedures, etc. Maps and plans in particular can be used also in archaeological or preservation research, iconographic records can serve as basis for restoring interventions. Some information about this way of use of archive documents penetrates the public and gain stronger resonance, but usually they are paid too little attention to. With respect to „raising the profile" of the archives, great significance came from the political changes in Czech Republic after 1989, which at the beginning of the 1990s brought civil rehabilitation and compensation for the victims of the totalitarian regime, as well as property restitution along with privatization of state owned enterprises or nationalized assets. While the privatization and nationalization had an impact on the spatial situation of archives and eventually led to construction of new expedient archival buildings (Ryantová 2015), the practical need for finding archive documents to substantiate the proprietary or civil claims signified not only the increased burden for the archives on the one hand, but also the strengthened prestige and importance of the archives in the eyes of the public. In this way the archives became part of the general awareness as important memory institutions, required for functioning and maintaining the archival wealth for future generations.

With respect to archives from the outside point of view, more important are the cultural-educational objectives and goals of the use of archive documents, which also correspond to other forms apart from the study of the archive documents in the archives, which represents a basis for this usage, the most common activities involve lectures and exhibitions, which have a role in propagation of the archives and in other aspects, especially those taking place outside the archives.

\section{Archival exhibitions since 1990}

The tradition of archival exhibitions or exhibitions of archive documents reaches in Czech Republic back to the period in Czechoslovakia after second world war, or to the period after the communist coup d'état in February 1948, when the role of their ideological subtext was significant. One of the first exhibitions was the „Národní tradice v díle Zdeňka Nejedlého (1878-1962) “ „National tradition in the works of Zdeněk Nejedlý (1878-1962)", the minister of education and enlightenment, historian and first secretary of state and most importantly ideologist of Czechoslovakia after the communist coup. The exhibition took place in the Museum of Applied Arts in Brno in February and March in 1953 and it showed the historical development since the „dawn of history" through the Hussite movement, highlighted by Z. Nejedlý, and conversely deprecated period from the Battle of White Mountain in 1620 and the end of the Thirty Years 'War („dark age") to the national revival from the end of the $18^{\text {th }}$ and during the $19^{\text {th }}$ century, and further to the present days and „bright tomorrow" of the communist state at the time. The exhibits for the exhibition were mostly borrowed from museums, but it also included archive documents from the Brno City Archives, the Jihlava City Archives and the Moravian Provincial Archives (which changed its name for several decades to State Regional Archives), whose director (dr. Jiří Radimský) participated in the ideological and organizational management of the exhibition (Výstava 1953).

\subsection{National exhibition of archival documents 1958}

This exhibition basically became just a prelude to an spectacular event, which followed after five years - in addition, it was based on archival exhibits exclusively: Celostátni výstava archivnich dokumentů (National Exhibition of Archival Documents) with the subtitle Od hrdinné minulosti k vitézstvi socialismu (From Heroic Past to the Victory of Socialism) took place in Prague in the most prominent spaces in the Prague Castle (Vladislav Hall, Old Chamber, Rudolph's Gallery, Spanish Hall and adjacent spaces) from $23^{\text {rd }}$ May to $30^{\text {th }}$ August in 1958 and to this day, it represents by its nature, scope and duration the biggest and the most significant event of this kind in the history of both Czechoslovakia and Czech Republic. The exhibition was initiated by then Minister of Interior Rudolf Barák based on the resolution made by political bureau of the Communist Party Central Committee. It was firstly a political matter, which also had a significant social and cultural impact. In sum, there were 1700 of archive documents from funds and collections of Bohemia, Moravia and Slovakia exhibited simultaneously - documents, manuscripts, but also younger act materials with an emphasis on the "possibility of drawing attention by its content rather than the appearance, which is often very understated, but not even in this sphere artistic binding and tastefully edited documents are no exception", maps and plans were also exhibited (Celostátni výstava 1958; Samberger et al. 1958; Benešová 2004b, 
Marie RYANTOVÁ: Using Archives in the Czech Republic as an Important Formative Factor of Historical Awareness and a Means of Providing Publicity For Archives: Archival Exhibitions, 171-180

pp. 150-154). Other exhibits (statues, sculptures, paintings, engravings, etc.) represented only small addition. The presentation of authentic original documents was specially emphasized. Tangible items and some of the written exhibits were supplied by libraries, museums and the National Gallery in Prague, 14 documents related to Slovakia were borrowed from the National Archives of Hungary in Budapest. In order to make this exhibition, large exhibition committee, ideological commission, creative and architectural commission were established, historical-archival group was created with Zdeněk Šmberger as its president, later head of the Central State Archives. Group of authors was also established, in order to process the Slovak part of exhibition, a group processing screenplays, textual group, deposit group. The selection of exhibits was made by the archives' employees in cooperation with librarians and employees of museums, advice and recommendations were provided by historians from scientific institutions and universities; there were 150 people participating in the exhibition preparation (apart from the exhibition honorary presidium), according to the extant documents, the exhibition lasted only for three and a half month. There was an emphasis on the exhibition spaces mentioned above, which were understood „themselves“ as „suitable environment for the exhibits installed“, while it was probably the first time the Prague Castle was accessed so extensively. Rather remarkable was the attention devoted to the showcases, which were made to prevent the archive documents from being damaged by the dust and daylight, as well as to the selection of lighting - fluorescent lamps with glass filters and protective paint. From today's perspective, to exhibit original documents for three months is unthinkable, even though (according to contemporary witnesses) ${ }^{2}$ the exhibited book were being opened gradually on different pages. The exhibition had similar chronological structure as the exhibition previously mentioned and was divided into eight periods, which included: 1) the oldest time in Czechoslovakian history (from 1415, or 1420), 2) Hussite revolutionary movement, 3) the period before the Battle of White Mountain (to 1620), 4) the so-called dark age and national revival (to 1848), 5) from the revolutionary year 1848 to the birth of Czechoslovakia in 1918, 6) the period of the „first Czechoslovak Republic“, e.i. until the Munich Agreement (1918-1938), 7) second world war („Czech and Slovak people's fight against Hitler's occupation and for national and social liberty“) and 8) the developments after the second world war with „building socialism“. It is obvious from this division and the terminology used, that the exhibition maintained then mandatory ideological subtext, which was noticeable also in the printed catalog, again published with Zdeněk Nejedlýs preface (Neje$d l y$ ), particularly in the youngest phases of history or in the arguments highlighting the importance of archive documents in terms of rivalry in then polarized world, divided by the iron curtain into inconsistent units ${ }^{3}$. From this perspective, the exhibition hasn't escaped the period rhetoric. Much more remarkable was the fact, that the historical periods before 1848 were given relatively large space and many exhibits - approximately half (813), while the „condemned“ dark age (1620-1848) was represented rather significantly. Part of the exhibition was even devoted to the presentation of the Czech king's crown jewels from the era of Charles IV. Mainly due to the archivists themselves, it was possible to select and present interesting documents, in order to have a particular image of national history. It might have also been the reason for the exhibition's success and high visit rate (despite its high budget, it was profitable) - it made it possible to show the importance of archive documents and also the archives for formation of historical awareness. The archives presented themselves not only by borrowing the exhibits, but also in separate section of the exhibition, which was devoted to them and to the archive science.

Nationwide archival exhibition of archive documents in 1958 represents certain divide - on one hand, it concluded „darker period" in history of Czechoslovakia with the political processes in the 1950s (architectural solution of the exhibition was prepared by architects, who were held in prison at that time for political reasons, exhibits were installed, inter alia, by political prisoners, and crafts by other prisoners, who were pardoned after the exhibition ending (Sak 2012, p. 183; Benešová 2004b, p. 154), paradoxically, some people participating in the preparation of the exhibition were punished, even though „only“ by failed staff screening), on the other hand, it already pre-empted some changes, that gradually came at the end of the fifties in other spheres of life at the time, especially in science and

\footnotetext{
2. Interview with Dr. Eduard Šimek (*1936), $20^{\text {th }}$ May 2016.

3. „We also have our documents and they are presented by this exhibition before the public and before everyone who wants to know the truth. Both the victorious for encouragement and joy, and the opposing, lost and unsuccessful for lesson and warning, both indisputable as they are documents. Our enemies' attempts to falsify our history, our past and our character and our people's position in the world will prove to be vain. This hate-filled perversion will roll off the documents like water off a duck's back, available here to all those who want to know the truth." (Nejedlý, s. 7).
} 
Marie RYANTOVÁ: Using Archives in the Czech Republic as an Important Formative Factor of Historical Awareness and a Means of Providing Publicity For Archives: Archival Exhibitions, 171-180

culture. Beside the mentioned impact on the development of historical awareness, this exhibition also inspired further actions of similar kind, especially in South Bohemia: in 1960, there was an exhibition called Hluboká 1960 - Podíl jižních Čech na tvorbé národního pokladu (Hluboká - Participation of the South Bohemia in the formation of national treasure), held in Hluboká Castle, at the time with Aleš South Bohemian Gallery, and its goal was to document the history of South Bohemia both using the archive documents and the painted pieces of work (Hluboká 1960).

\subsection{Other archival exhibitions}

The exhibition from 1958 has never been repeated in its original extent, not even the plans to present some of the most significant archive documents from the World Exhibition in Brussels in 1958 weren't realized, especially due to the difficulties related to exhibiting originals, nevertheless there was never an exhibition of facsimiles or dummies either (Benešová 2004b, pp. 154-155). In the 1960s and 1970s, there were other exhibitions presenting mainly archive documents from the Central State Archives - among the most significant was the exhibition called Mirové snahy Jiř́ho z Podébrad $v$ dokumentech (Documented Peacemaking Efforts of George of Poděbrady), which was a contribution to the celebration of the 500th anniversary of the George of Poděbrady's peace plan and it took place in the vault of the Czech Crown Archives from June to September 1964, or the exhibition called 450 let dolování v Jáchymově (450 Years of Mining in Jáchymov), held in 1966, which used parchments, maps, mountain books and many other document to remind the rich history of Czech mining (Benešová $2004 b$, pp. 154-156). Most of other exhibitions were less extensive and ideologically oriented (with respect to then current political, historical and cultural topics) and usually presented only copies or reproductions, in addition without any publicity and impact on public ${ }^{4}$. Some archive documents were sporadically lent abroad, even though some of the events or participations never happened (the exhibition Génius českého a slovenského národa (Genius of the Czech and Slovak Nations) in Paris in 1970, Člověk a jeho svèt - Civilizace (Mankind and Its World) in Montreal in 1973) and in most cases, these were lent to other socialist countries (Moscow 1970 - Československo 1970 (Czechoslovakia 1970), Krakow and Warsaw 1978 - Československo - Polsko. Staleti sousedstvi a prátelstvi (Czechoslovakia - Poland. Centuries of Neiborough and Friendship) (Benešová 2004b, pp. 160-162).

The opportunity to present interesting archive documents, in smaller scale in comparison with the exhibition in 1958 and with many additional exhibits (again next to crown jewels), was offered by another nationwide exhibition prepared in 1978 for the $600^{\text {th }}$ anniversary of the king Charles IV's death, also in the Prague Castle, named Doba Karla IV. v dèjinách národũ ČSSR (Era of Charles IV in the History of the Czechoslovak Socialist Republic Nations) (Burian 1987). The main organizer was the Ministry of Culture and the President of the Czechoslovakia's Office, and also in this case the exhibition had significantly ideological nature, especially as it should have counterbalanced the events held in West Germany. This time, only around one hundred of archive documents were exhibited, but it hadn't received required care, so the head of the Central State Archives protested against their undignified installment (when they served as „decorative accessory“ for other exhibits) and incorrect signs (Benešová 2004b, pp. 158-159). This also led to the decrease of their effect, even though the exhibition experienced an extraordinary public interest.

In the 1980s, it was already possible to participate in exhibitions held abroad (for example, František Josef I. 1848-1880 (Franz Josef I 1848-1880)" - Vienna 1984, Zahrady a parky ve Florencii (Gardens and Parks of Florence) - 1986, Rudolf II. a jeho doba (Rudolph II and His Times) - Essen 1988), in 1988, for the 70th anniversary of the establishement of Czechoslovakia, there was an exhibition held in Lobkowicz Palace in the Prague Castle, small in its scale, but significant and successful with the name Poklady Archivu Ceské koruny (Treasures of the Archives of the Crown of Bohemia), which presented 11 most important constitutional documents related to the Czech state's history, it was also accompanied by specialist lectures. In the time of gradually increasing resistance against the communist regime, exhibition of these documents played an undeniable role while reminding the glorious history of the Czech state, and again it contributed to strengthening the historical awareness,

4. E.g. „Komuna 1871 a její ohlas u nás“ / „Commune 1871 and Its Public Acceptance“ (1971), „Formování marxistické levice 1920-1921“ / „Forming the Marxist Left 1920-1921“ (1971), „Rok 1848 a pražští dělníci“” „The Year 1848 and the Prague Proletariat“ (1973), „Sjezdy KSČ 1920-1976“ / „Congresses of Communist Party of Czechoslovakia 1920-1976“ (1976), Klement Gottwald 1896-1953“ (1976) or from the older documents „Nevolnické povstání 1775“ / „Uprising of Serfs in 1775“ (1975), but also „Broumov. 1258-1848“ (1981). (Benešová, pp. 156, 158, 160, and overview pp. 176-181). 
Marie RYANTOVÁ: Using Archives in the Czech Republic as an Important Formative Factor of Historical Awareness and a Means of Providing Publicity For Archives: Archival Exhibitions, 171-180

as well as to the positive perception of archives and archive science. From $17^{\text {th }}$ October to $4^{\text {th }}$ December in 1988, the exhibition was visited by 60000 people, who came from around the country and waited from early hours in long queues to enter the exhibition spaces (Benešová, 2004b pp. 162-163).

\section{Archival exhibitions after 1990}

\subsection{Exhibitions in the Central State Archives, later national archives}

After 1989, no ideological obstacles prevented exhibitions and it was possible to hold exhibitions with various topics. Already one of the first exhibitions held by the Central State Archives, which presented in the Prague Castle the Desky zemské - klenot Královstvi českého (The Land Rolls - A Jewel of the Kingdom of Bohemia), experienced an extraordinary success and it also contributed to strengthening the historical awareness: during its presentation from $20^{\text {th }}$ September to $25^{\text {th }}$ November in 1990 it was visited by 145000 visitors (Benešová 2004b, pp. 164). In subsequent years, the Central State Archives were burdened by other activities, mainly by the official accessing agenda related to the political changes, but also by taking over the archive documents from abolished offices and institutions and solving the spatial issues, other archives also experienced this situation. Nevertheless they participated in lending to many exhibitions, both domestic and foreign. Among the domestic exhibitions, one of the most significant was the exhibition Rudolf II. a Praha. Císařský dvir a rezidenčni mèsto jako kulturni a duchovni centrum stredni Evropy (Rudolf II and Prague. The Court and the City), which took place in 1997 (Fuč́ková et al. 1997), or Sláva barokni Cechie (The Glory of the Baroque Czechia) four years later (Vlnas 2001), while many institutions participated in both. The participation of the then Central State Archives was particularly important in two exhibitions in Italy - the Central State Archives borrowed an extensive set of maps and plans from the Family archive of Tuscan Habsburgs' fund, first for the exhibition, which took place in 1991 in the National Archives in Florence (Lotrinské Toskánsko v mapách Státního ústredního archivu v Praze (Lorraine Tuscany on Maps of the Central State Archives in Prague), and later for similar exhibition in 1997 in Siena (Rukopisy a mapy Státního ústredního archivu v Praze. Poklad toskánských velkovévodi (Manuscripts and Maps of the Central State Archives in Prague. Tuscan Grand Dukes Treasures). Both of these exhibitions became an important evidence of the Czech and Italian archivists' cooperation and contributed to the Czech archive science's presentation abroad. The anthology of materials exhibited was later presented in Prague, first at the exhibition Italské Toskánsko na mapách 18. a 19. stoletil (Italian Tuscany Illustrated on Maps and Plans of the $18^{\text {th }}$ to $19^{\text {th }}$ Centuries (1992) and later at the exhibition Siena v Praze (Siena in Prague), held in 2000 in cooperation with the National Gallery in Prague and with the archive and university in Siena, so it was possible to accompany the exhibition by works of art (Benešová 2004b, pp. 164).

More opportunities to hold its own archival exhibitions came after the construction of the archival area in Chodovec (Ryantová, 2015). At the occasion of the inauguration and the opening of the archives, there was a representative exhibition from $1^{\text {st }}$ to $31^{\text {st }}$ October 2001 called Poklady Státního ústredního archivu v Praze. Český a československý stát v dokumentech 1158-1990 (Treasures of the Central State Archives in Prague. The State of Bohemia and Czechoslovakia in Documents. 1158-1990), which illustrated the constitutional development. This exhibition offered to the widest possible audience the alleged "secrets" hidden in depositories, simultaneously it presented the Czech archive science and helped to understand the archive's functionality as the guardian of the nation's memory and to learn the national history in unthought-of context. It had 30000 visitors, who were attracted mainly by the original of one of the most famous document in Czech history - the Golden Bull of Sicily from 1212, but also by the concept of the Declaration of independence written by T. G. Masaryk in $14^{\text {th }}$ October, 1918 in Washington and donated to Vaclav Havel in 1991 by the US Congress (Benešová 2004b, pp. 166-168; Gregorovičová 2001).

Later, there were some interesting exhibitions held in the then Central State, today National Archives as well, usually related to the anniversary of the opening of the archival area and also at the occasion of the Czech Statehood Day, $28^{\text {th }}$ September (St. Wenceslas Day) - in 2002 (from $28^{\text {th }}$ September to $31^{\text {st }}$ October) it was the exhibition called Čská panovnická a státni symbolika. Vývoj od středověku do současnosti (Czech Sovereigns' and State's Symbols. Their Evolution from the Middle Ages up to the Present), which presented the monarch's seals and various versions of the Kingdom of Bohemia's crest and later Czechoslovakian national coat of arms, but also banners and flags, non-ap- 
proved national flag's drafts, sealers, decorations and badges or recordings of the national anthem and other significant songs. It was also accompanied by series of lectures and presentations or invitations in media (Benešová, 2004b, pp. 168; Sedláček - Gregorovičová 2002). There is no doubt, that this exhibition had a significant share in forming historical awareness. Another purely archival exhibition was the one called Aby na nikoho a nic nebylo zapomenuto (Nothing and Nobody Should Be Forgotten), which took place from $1^{\text {st }}$ to $31^{\text {st }}$ of October in 2004 (Benešová 2004a).

A significant exhibition named Karel IV., císař z Boži milosti (Charles IV - Emperor by favor of the divine mercy), held in the Prague Castle in 2006 (Fajt - Drake 2006), was accompanied by a separate exhibition of the National Archives using the archive documents from the Jihlava City Archives, „Doba vlády Karla IV. a jeho rodiny v archivních dokumentech“ (,The Era of the Reign of Charles IV and His Family in the Archival Documents and Records"), which took place from $20^{\text {th }}$ April to $21^{\text {st }}$ May in 2006 (Doba vlády Karla IV.). A lot of interest was aroused by the exhibition Zlatá bula sicilská 1212. 800 let mezi realitou a mýty (The Golden Bull of Sicily 1212. 800 years between reality and myth), $27^{\text {th }}$ to $30^{\text {th }}$ September in 2012 or the Jirí z Podébrad, husitský král - prítel míru (George of Poděbrady, king of Hussites - friend of peace), $26^{\text {th }}$ to $29^{\text {th }}$ September in 2014, even though they both lasted for only couple of days. Furthermore, other separate exhibitions were held in the National Archives (for example, Dëjiny českého novinárství a českých novinárských spolkũ (History of Czech Journalism and Czech Journalist Societies), 2002; Skončeno a podepsáno. Drama Pražského povstáni ve fotografii (Accomplished and Signed. The Prague Uprising in Pictures) 2003; Skrytý privab dopisu toskánských Habsburkù (Hidden Charm of the Tuscan Hapsburgs' Letters), 2003; Museli pracovat pro Řiśsi (They Were Forced to Labour in the Reich), 2004; Návrat ke kořenưm (Back to One's Roots), 2005; Expo Brusel 1958 (Expo Brussels 1958) and Osudové osmičky/(The Fatal Eights) 2008; etc.), or those prepared in cooperation with other institutions or archives (for example, $Z$ pokladiu stredočeských archivi 1166-1990 (Treasures of the Central Bohemian Archives. 1166-1990), 2003), naturally, the archives would lend many documents to other exhibitions ${ }^{5}$. In 2016, at the occasion of the $700^{\text {th }}$ birth anniversary of the Charles IV, an exposition called Archiv České koruny. Listinný poklad Karla IV. (Czech Crown Archives. Written treasure of Charles IV), 28 ${ }^{\text {th }}$ to $31^{\text {th }}$ October 2016 is in preparation.

\subsection{Limitations and restrictions accompanied the archival exhibitions}

Although by constructing new archive buildings the National Archives gained also exhibition spaces, the preparation and the exhibition of the archive documents are accompanied by various limitations. If the originals are being exhibited, which increases the attractiveness of every exhibition, it is in the interest of their protection to count with some extra limits when it comes to the optimal temperature $\left(\max 18^{\circ} \mathrm{C}\right)$ and the light intensity, in addition the duration is usually limited to one month, in case of extension the most endangered exhibits are replaced by copies (faksimiles). Given the primary goal of archivists and preservers is to maintain the archive documents for the future generations, there is a policy in the National Archives in Prague, that the originals can be exhibited only once in a quarter of a century (Benešová 2004b, pp. 166). This rule similarly applies to other archives, other restrictions regarding the exhibitions are given by the financial requirements and personal possibilities (this is the reason, why in 2009-2011 and in 2003, there were no separate exhibitions held in the National Archives), also the accessing the exhibition for visitors in the archival building (especially outside the city center) has its specifics.

\subsection{Exhibitions in the special and city archives}

With that in mind, the exhibitions of the archive documents were held in the Czech Republic mainly in the archives, linked to institutions which are oriented at holding exhibitions - e.i. in the National Museum Archives (or National Museum), the National Gallery Archives, or National Gallery, where the archive documents from personal funds in the form of letters, sketches, invitations, photographs etc. represent an addition to an exhibition presenting artists and their work (see Annual reports of the National Gallery Prague 2000-2014) or the Literary Archives. List of individual exhibitions extends the possibilities of this study, worthy of note is the extensive exhibition prepared in 1996

5. The overview of exhibitions held and contributed by the National Archives in Prague in 1954-2004 is presented by E. Benešová. For subsequent years, information about the exhibitions can be found in the annual reports of the National Archives' activities, available on-line. 
Marie RYANTOVÁ: Using Archives in the Czech Republic as an Important Formative Factor of Historical Awareness and a Means of Providing Publicity For Archives: Archival Exhibitions, 171-180

for the $150^{\text {th }}$ anniversary of the oldest public archive in Bohemia - the National Museum Archives, which focused solely on the archive documents and in 60 showcases it presented their representative collection and also the development and content of the archive's funds and collections; unfortunately, no catalog was published (Ryantová, 1997a, 1997b). The wealth of the National Museum Archives was also presented at the exhibition of alba amicorum (Wade 1995) or the dancing masters exhibition (Ryantová, 2000) or the exhibition devoted to the 200th birth anniversary of the great Czech historian František Palacký (Ryantová, 1998, 1999a) ${ }^{6}$. In recent years, there was an interesting photography exhibition Hradni fotoarchiv 1918-1933 (Prague Castle Photographic Archives 1918-1933), presented in Prague $\left(28^{\text {th }}\right.$ October $2009-6^{\text {th }}$ July 2010) and in Bratislava $\left(27^{\text {th }}\right.$ October $2010-27^{\text {th }}$ March 2011), but also in other regions of the Czech Republic (Béličová et al. 2008; for more information see Annual reports of the Natinal Museum Archives) ${ }^{7}$.

The Literary Archive of the Museum of Czech Literature (Památnik národniho pisemnictvi) focuses primarily on the exhibitions for various literary figures' anniversaries - for example, the exhibition Vsechny krásy svetta (All the beauties of the world) was organized in this way, for the $100^{\text {th }}$ birth anniversary of the poet and Nobel laureate Jaroslav Seifert $\left(26^{\text {th }}\right.$ September $2001-13^{\text {th }}$ January 2002) or the exhibitions reminding other Czech writers, some of the exhibitions were presented even in other places of the Czech Republic or abroad, or were borrowed from abroad, and not only the archive documents, but also the works of art (paintings, drawings, graphics) ${ }^{8}$.

Among the archives with extensive exhibition activities we can find also the Prague City Archives, which hold exhibitions both independently and in cooperation with its partner, the City of Prague Museum, while it has its own spaces in the city center (e.g. Ledvinka 2000, 2003, 2004; Ledvinka and Cornej 2015; Valeś 2002; Ratajová 2008; Mendelová and Státníková 2011). Similarly equipped is the Archive of Charles University, which has lately been also holding various exhibitions (e.g. Cajthaml 2015), the Ostrava City Archives also presents itself in this manner every year (e.g. Novotná 2016).

\subsection{Exhibitions in the regional archives}

If the archives mentioned and their constructions had and have nationwide and transregional reach, the regional and the district archives subordinated to them hold in the republic (often in cooperation with related institutions, mainly museums - apart from participating in numerous other exhibitions with borrowings) primarily regionally oriented exhibitions, usually dedicated to current anniversaries and sometimes with short duration or one-time nature (at the occasion of various celebratory events, etc.). This way of exhibitioning is usually very attractive, and next to the informative value and importance for deepening the historical knowledge, its role is also valuable for strengthening or forming the relation with given region, as well as for forming the historical awareness of it. These exhibitions have lately been prepared in terms of the International Archives Day and accompanied by excursions or lectures. At the same time, it is possible to use the exhibition spaces or at least the showcases, remembered while building or reconstructing the archival buildings. Information about the exhibitions can be found on the archives' websites and in subsequent annual reports and articles in specialist journals (eg. Holub 2013; Nohovcová and Vañata 2015; Pflegerová 2016; Körnerová Chládková 2016).

\section{Conclusion}

This text is far from being complete when it comes to presented information, but its goal was to call attention to the special archival exhibitions as distinctive form of the use of archive documents, which serves to propagate the archives, but also has an invaluable significance for the formation of historical awareness in both nationwide and regional scale. New archival buildings, built in Czech Republic after 1990, provide a valuable opportunity, they often include exhibition places or showcases at least, the exhibitions them-selves are accompanied by lectures, often in the context of the International Archives Day celebrations, and they contribute to strengthening the archive science's significan-

6. This exhibitions named „František Palacký. Gelehrter, Politiker, Europäer (1798-1876)“ took place in the autumn 1998 in Österreichische Nationalbibliothek Wien (Ryantová, 1999b).

7. In this case, we exhibited the reproductions.

8. The overview of the exhibitions 2001-2016 available at: http://pamatniknarodnihopisemnictvi.cz/2001/. 
Marie RYANTOVÁ: Using Archives in the Czech Republic as an Important Formative Factor of Historical Awareness and a Means of Providing Publicity For Archives: Archival Exhibitions, 171-180

ce as a part of informational and memory system of the society. Exhibition of originals, highly attractive for visitors, is (unlike the case of digital accessing of archive documents) accompanied by some limitations related to the optimal temperature and light, but also the duration of exposition, the exhibitions also have specific financial and personal requirements, still this way of using archive documents deserves our attention in the future.

\section{References}

Act no 499/2004 Sb., concerning the archives and record management and the change of some laws (Zákon o archivnictví a spisové službě č. 499/2004), Statute Book of the Czech Republic 2004, No. 499 - https://portal. gov.cz/app/zakony/zakonPar.jsp?idBiblio $=58364 \&$ fulltext=Z $\sim$ C3 - A1 kon $\sim 20 \mathrm{o} \sim 20$ archivnictv $\sim$ C3 $-\mathrm{AD} \& \mathrm{rpp}=$ 15\#local-content (accessed on 31.05.2016).

Běličová, M., Jůn, L., Novozámská, M., Vandrovcová, M. (2008). Hradnífotoarchiv/ Prague Castle Photographic Archives 1918-1933. Praha.

Benešová, E. (2004b). Výstavy a propagace archivu. [Tj. Státního ústředního, dnes Národního archivu v Praze]. In: Benešová, E. (ed., 2004), Aby na nic a na nikoho nebylo zapomenuto. Kjubileu ústrédního archivu českého státu 1954-2004. Praha, pp. 149-186.

Benešová, E. (ed., 2004a), Aby na nic a na nikoho nebylo zapomenuto. K jubileu ústréedního archivu českého státu 1954-2004, Praha.

Burian, J. (1978). Doba Karla IV. v dějinách národů ČSSR (Průvodce výstavou). Praha.

Cajthaml, P. (2015). Listopady / Novembers. Výstava Univerzity Karlovy k výročí 17. listopadu 1939 a 1989. In: ČS v roce 2014. Ročenka Ceské archivni společnosti. Praha, pp. 145-147.

Celostátni výstava archivních dokumentů v Československu. Praha, květen - srpen 1958. Praha 1958.

Doba vlády Karla IV. a jeho rodiny v archivnich dokumentech, Praha 2006.

Fajt, Jiř́ - Drake-Böhm, Barbara (edd., 2006). Karel IV., císař z Boží milosti. Kultura a umění za vlády Lucemburků 1310-1437. Praha.

Fučíková, E., Bradburne, J. M., Bukovinská, B., Hausenblasová, J., Konečný, L., Muchka, I., Šroněk, M. (edd., 1997). Rudolf II. a Praha. Cisařský dvirr a rezidenčni mésto jako kulturni a duchovni centrum střední Evropy. Kata$\log$ vystavených exponátů. Praha.

Fučíková, E., Bradburne, J. M., Bukovinská, B., Hausenblasová, J., Konečný, L., Muchka, I., Šroněk, M. (edd., 1997). Rudolf II and Prague. The Court and the City. Prague - London - New York.

Gregorovičová, E. (ed., 2001). Poklady Státniho ústředního archivu v Praze. Český a československýs stát v dokumentech 1158-1990. Praha.

Hluboká 1960 - Podil jižnich Čech na tvorbè národního pokladu. Archivni dokumenty. Kulturnè historické doklady. Výtvarné umění. Hluboká nad Vltavou 1960.

Holub, P. (2013). Pomocné vědy historické v přednáškách a výstavách. In: ČAS v roce 2012. Ročenka České archivni společnosti. Praha, pp. 107-110.

Körnerová Chládková, M. (2016). Výstavní dům Stará radnice v Jindřichově Hradci a expozice „Z historie městské správy a samosprávy“. In: ČAS v roce 2015. Ročenka České archivní společnosti. Praha, pp. 188-189.

Ledvinka, V., Čornej, P. (ed., 2015). Praha Husova a husitská 1415-2015. Publikace k výstavě. Praha.

Ledvinka, V. (ed., 2000). Osm stoleti pražské samosprávy. Výstava o vývoji pražské městské správy od 13. století do roku 2000. Prưvodce výstavou. Praha.

Ledvinka, V. (ed., 2003). Praha - Čechy - Evropa. 1100 let kulturní, hospodářrké a politické metropole střední Evropy. Publikace k výstavě. Praha.

Ledvinka, V. (ed., 2004). Praha - Videñ. Dvě evropské metropole v běhu staletí. Publikace k výstavè. Praha.

Mendelová, J., Státníková, P. (edd., 2011). Pražské rokoko: kulturni a společenský život v Praze 1740-1791. Praha.

Museum of Czech Literature (Památník národniho pisemnictvi). Available at http://pamatniknarodnihopisemnictvi.cz/2001/ (accessed on 31.05.2016).

National Archives Prague. Annual reports. Available at http://www.nacr.cz/H-archiv/vyr_zpravy.aspx (accessed on 31.05.2016). 
Marie RYANTOVÁ: Using Archives in the Czech Republic as an Important Formative Factor of Historical Awareness and a Means of Providing Publicity For Archives: Archival Exhibitions, 171-180

National Archives Prague. Exhibitions. Available at http://www.nacr.cz/A-onas/J-vystav.htm (accessed on 31.05.2016).

National Gallery Prague. Annual reports. Available at http://www.ngprague.cz/vyrocni-zprava (accessed on 31.05.2016).

National Museum Prague Archives. Annual reports. Available at http://www.nm.cz/Historicke-muzeum/Oddeleni-HM/Archiv-Narodniho-muzea/ (accessed on 31.05.2016).

Nejedlý, Z. (1958). Předmluva. In: Šamberger, Z., Pletka, V., Holl, I., Lameš, J. (1958), Celostátní výstava archivnich dokumentü. Od hrdinné minulosti k vitězství socialismu. Praha, pp. 7-12.

Nohovcová, L., Vaňata, J. (2015). Fotografie Škoda na výstavách. In: ČAS v roce 2014. Ročenka České archivní společnosti. Praha, pp. 134-137.

Novotná, J. (2016). Výstava Černé umění za časů černé Ostravy aneb tiskařství v průmyslovém velkoměstě. In: ČAS v roce 2015. Ročenka České archivni společnosti. Praha, pp. 190-191.

Pflegerová, Š. (2016). Výstava Plzeň - prvních pèt století. In: ČAS v roce 2015. Ročenka České archivni společnosti. Praha, pp. 185-187.

Ratajová, J. (red., 2008). Pražský student. Univerzitni studenti v dějinách Prahy. Publikace k výstavě. Praha.

Ryantová, M. (2015). Archive Buildings in the Czech Republic After 1990: the „Czech Archival Wonder“ and the Present Situation. In: Atlanti. Review for modern archival theory and practice, 25, N. 2, pp. 53-60.

Ryantová, M. (1997a). 150 let Archivu Národního muzea. In: Vèstnik Asociace českých a moravskoslezských muzei a galerií, 1-2, pp. 11-13.

Ryantová, M. (1997b). 150 let Archivu Národního muzea. In: Archivni čtvrtletník 5.

Ryantová, M. (1998). Výstava k 200. výročí narození Františka Palackého. In: Archivní čturtletník 6, č. 3-4, pp. 52-57.

Ryantová, M. (1999a). František Palacký (14. 6. 1798 - 26. 5. 1876). Seznam exponátů výstavy, uspořádané v Pantheonu Národního muzea ve dnech 16. června - 2. srpna 1998. In: Šmahel, F., Doležalová, E. (ed., 1999), František Palacký 1798/1998 Dějiny a dnešek. Sborník z jubilejni konference. Praha, pp. 537-556.

Ryantová, M. (1999b). Výstava k 200. výročí narození F. Palackého ve Vídni. In: Muzejní a vlastivédná práce 37 (Časopis Společnosti prátel starožitností 107), č. 1, pp. 50-51.

Ryantová, M. (2000). Taneční pořádky. In: Kuděj 2000/2, pp. 40-56.

Sak, R. (2012). Tu lásku, která původně byla určena Třeboni, jsem rozšíril na celé jižní Čechy, na celý kraj (12. 4. 2010). In: Ryantová, M. et al. (2012), Býti archivárem. Přednášky ze stejnojmenného cyklu poŕádaného v Českých Budějovicích. Pelhřimov, p. 183.

Sedláček, P., Gregorovičová, E. (edd., 2002). Česká panovnická a státní symbolika. Vývoj od stréedověku do současnosti. Praha.

Šamberger, Z., Pletka, V., Holl, I., Lameš, J. (1958). Celostátni výstava archivních dokumentů. Od hrdinné minulosti $k$ vitězstvi socialismu. Praha.

Valeš, V. (ed., 2002). Doma v cizině. Česi ve Vidni ve 20. století. Zu Hause in der Fremde. Tschechen in Wien im 20. Jahrhundert. Katalog výstavy. Praha.

Vlnas, V. (ed., 2001). Sláva barokni Čechie. Umèni, kultura a společnost 17. a 18. století. Praha.

Výstava Národni tradice v díle Zdeňka Nejedlého. Umělecko-průmyslové muzeum v Brně, únor - březen 1953. Brno 1953.

Wade, M. (1995). Eine Ausstellung von Stammbüchern in Prag. In: Wolfenbütteler Barock-Nachrichten 22/2, pp. 135-136.

Typology: 1.04 Professional Article

Submitting date: 05.02.2016

Acceptance date: 20.02.2016 